Article

\title{
Achieving Cost Benefits in Sustainable Cooperative Housing
}

\section{José Coimbra * and Manuela Almeida}

Department of Civil Engineering, School of Engineering, University of Minho, Campus de Azurem, Guimaraes 4800-058, Portugal; E-Mail: malmeida@civil.uminho.pt

* Author to whom correspondence should be addressed; E-Mail: josepaulocoimbra@gmail.com; Tel.: + 35-122-951-9288; Fax: + 35-122-957-8356.

Received: 13 September 2012; in revised form: 24 October 2012 / Accepted: 18 December 2012 / Published: 4 January 2013

\begin{abstract}
The cooperative housing sector is directed at low and medium income residents who cannot afford to buy their homes in the regular private market. Due to social housing legislation, it is possible to build cooperative housing below regular market costs and use tax benefits, therefore providing affordable dwellings to their owners. Traditional cooperative housing used to provide less comfort and higher running costs in indoor and domestic hot water heating than in standard construction. However, cooperative housing has started to change its method of traditional construction towards sustainable construction, in order to benefit from the savings on energy consumption and domestic water as well as to provide an improvement as far as the comfort of its residents is concerned. Therefore, in this article, the savings in electricity and natural gas in different building settlements, calculated for Madalena building - sustainable construction - and for Azenha de Cima building - traditional construction - will be presented, according to two different criteria of calculation: efficiency of dwellings at a pre-determined standard level of indoor comfort opposed to real consumptions made by residents. For each building under analysis, an energy audit and further monitoring were brought in, in order to issue an energy evaluation according to the Portuguese energy agency rules. Results showed an expected decrease of the operational costs of natural gas and electricity, obtained by the use of efficient building systems and equipment, as well as a decrease of the payback period for each situation.
\end{abstract}

Keywords: cooperative housing; controlled costs; sustainable construction; energy efficiency 


\section{Introduction}

The construction sector uses a large part of the planet's natural resources and now it is becoming essential to achieve a global agreement to replace the non-renewable and non-self-sufficient resources and materials with other more sustainable ones. The planet is going through a critical phase of heavy use of natural resources, which could be exhausted in the near future. The over-use of natural resources, including fossil fuels, is releasing an excessive emission of gases into the atmosphere such as carbon dioxide, with a consequent impact on the planet's global warming, and damages to the environment. Changes in global climate, exhaustion of natural resources, pollution and deconstruction are unsustainable [1]. In addition, the excessive demand for raw materials, as well as increased demand for fossil fuels like oil, has caused an exponential increase in their cost. Moreover, it is expected that energy costs will tend to rise in the forthcoming decades, which will increase costs even more, due to the predictable shortage of fuel [2].

However, these phenomena have a very particular effect in Portugal, which relies heavily on imported energy and raw materials for construction. Portuguese families of the middle class and lower-middle class have increasing difficulty in obtaining housing due to the strong economic downturn that has plagued Europe and the United States, the rising cost of living, low incomes or even unemployment, and difficult access to credit [3]. On the other hand, potential buyers do not live, in general, in households with low energy consumption and natural resources, and do not enjoy comfortable housing from an environmental point of view, so it is necessary to conceive, design and follow new directions, with a view to reversing these negative conditions, and so (re)configuring a product that is both economically and socially sustainable and obtainable [4,5].

Sustainable cooperative construction is being developed by the cooperative sector in order to lower running costs in energy for indoor heating and for domestic hot water heating, and also to provide higher indoor comfort for its inhabitants. However, does economic effort in providing cooperative housing with sustainable features pay off?

To answer this question, it is necessary to determine average running costs in heating and DHW energy in sustainable and traditional cooperative housing and compare them with construction costs due to the introduction of sustainable features in this area. Moreover, it is mandatory to calculate which gaining costs can be obtained by using standard comfort indoor conditions and which gaining costs are obtained with real occupation of dwellings, also in traditional and sustainable housing.

This comparison of both standard comfort gains and real gains in energy in sustainable dwellings with construction cost will define a pay-back period interval.

\section{Challenges of Energy Efficiency in Cooperative Housing}

\subsection{The Issue of Research}

European and Portuguese Directives, including Directive 2002/91/EC on the Community Energy Performance of Buildings and Energy Certification requirement of new and existing buildings [6-8], have contributed to the increased responsibility of developers, builders, owners and residents. Since the activity of construction uses a large part of the planet's natural resources, a major agreement is 
essential to replace non-renewable, non-self-sufficient resources and materials, as well as saving energy and reducing emissions of $\mathrm{CO}_{2}$ to the atmosphere [2].

Most sustainable construction solutions in buildings are constrained by excessive costs or by very limited possibilities of choice for construction solutions of quality and, at the same time, low cost $[9,10]$. However, a deeper understanding of the costs and techniques used in the operation of energy efficient systems and their impact on social and economic savings of economic resources in families who live in cooperative housing over the life of the building is starting to be developed [11].

This knowledge of the economic benefits of sustainable buildings [5], as well as the idea of creating sustainable cooperative housing, was brought about due to the fact that, over the years, the cooperative sector has drawn up and synthesized a set of rules designed to form a particular model of organization and optimize cooperative activity and social responsibility, including standards-based quality management $[3,12]$.

From the adopted management model has emerged, amongst other factors, a need to respond adequately to the two main conditions for the cooperative sector in Portugal $[3,11,13]$ :

- The cooperative housing product is targeted at families of medium or medium-low financial income, mostly made up of young couples who are eager to have households with high standards of quality and superior design, space and building systems with more efficient equipment. Moreover, in purchasing cooperative housing, these families can achieve a house at a price $50 \%$ to $70 \%$ lower than the current real estate market while, at the same time, are able to follow current trends in the design and construction.

- Social housing cooperatives have tax benefits provided by law [14] as long as their housing projects comply with the technical and legal rules of social housing. These rules, which are official and supervised by IHRU-Institute for Housing and Urban Renovation, impose maximum areas and maximum costs of construction for dwellings.

However, cooperative housing, as well as general real estate housing in Portugal, is nowadays facing an increasing demand of regulatory compliance with standards of safety, efficiency, quality and functionality in homes, which translates as a substantial increase in cost of construction per square meter, although maximum areas and maximum costs remain unchanged [9].

Nevertheless, the use of sustainable construction solutions brings increased investment into the overall cost of the project, thus increasing the selling price of the dwellings. However, bearing in mind that the maximum cost of sale cannot be exceeded, there is a need to carefully manage the construction solutions to be adopted, using only those that fall within the acceptable costs. As a result, the cost of sustainable cooperative housing will be higher than traditional cooperative housing in $5 \%$ to $8 \%$ (numbers based on a recent assessment report of the payback period of sustainable construction in cooperative housing [15]) thus, putting the construction costs near the official limits but still feasible.

From this stage onwards, the management of cooperative housing projects must consider two new aspects:

- Although mandatory to comply with the official costs, it is possible to use high-efficient building systems and equipment [15];

- These high-efficient building systems and equipment will assure a reduction of the maintenance costs in what concerns consumption of gas and electricity for water and indoor heating. 
It is therefore the purpose of this work to find out how to design sustainable cooperative housing within the limits of costs and areas, using a case study methodology, in cooperative building construction in the district of Porto. By collecting and processing data of existing projects, the savings in electricity and natural gas of sustainable cooperative housing when compared with traditional housing, will be quantified. It will be shown that there is an effective contribution to improving respect for the environment and environmental comfort, resulting from the benefits obtained by using energy efficient building systems, taking into account running costs and maintenance.

\subsection{Study of Energy Efficiency in Residential Housing Cooperative}

To quantify the monthly savings (cost reduction in consumption of electricity and natural gas) of the residents of cooperative housing in dwellings with sustainable characteristics when compared to the same costs supported by the inhabitants of traditional cooperative dwellings, a study is presented comparing two cooperative housing settlements in the district of Porto. One is located in the city of Vila Nova de Gaia $\left(41.118040^{\circ} \mathrm{N}, 8.635900^{\circ} \mathrm{W}\right)$ and the other in the city of Senhora da Hora $\left(41.182666^{\circ} \mathrm{N}, 8.665556^{\circ} \mathrm{W}\right)$. The first settlement was designed and built following sustainable and energy-efficient construction principles in 2008/2009. The second one was built in the early 1990s, according to the usual features at the time for the construction of traditional cooperative housing. The studies performed show the energy efficiency of each dwelling in the two settlements with the quantification of the energy demand (electricity for space heating and natural gas for water heating) and related costs in order to compare the effort borne by the residents.

\subsubsection{Description of the Building Madalena, Vila Nova de Gaia}

The building of Madalena consists of a tenement building located in the city of Vila Nova de Gaia, containing thirty-nine dwellings, seventeen with two bedrooms and twenty-two with three bedrooms. It is placed in the inner urban zone at an altitude of $26 \mathrm{~m}$ and a distance to coast of $2 \mathrm{~km}$. The dwellings are developed in five floors, facing north and south. The area of façades, without glazing, is of $805.00 \mathrm{~m}^{2}\left(62.5 \%\right.$ of total façade area) and the area of glazing is $483.30 \mathrm{~m}^{2}(37.5 \%)$. All of them have strong thermal inertia, with thermal insulation in all exterior walls and in walls in contact with non-heated spaces and have no central heating or cooling systems, only portable heaters. All dwellings have a mechanical ventilation system as well as a domestic water heating system that consists of a gas heater and solar collectors.

\subsubsection{Description of the Building Azenha de Cima, Senhora da Hora}

The building of Azenha de Cima consists of a tenement building located in the city of Senhora da Hora, containing thirty six dwellings, twenty dwellings with two bedrooms, twelve with three bedrooms and four with four bedrooms. It is located inside the urban area, at an altitude of $50 \mathrm{~m}$ and a distance to coast of $2 \mathrm{~km}$ and the dwellings are developed in four floors, towards north, east and west. The area of façades, without glazing, is of $1,033.00 \mathrm{~m}^{2}(75.2 \%$ of total façade area) and the area of glazing is $341.00 \mathrm{~m}^{2}(24.8 \%)$. All of them have strong thermal inertia, have no insulation in any part of 
the envelope and they also do not have any central heating or cooling systems, only portable heaters. Hot water is produced with a 20 -year old gas heater and no solar collectors are installed.

\subsubsection{Description of the Housing Envelope and Mechanical Systems}

For the purpose of quantification and comparison of the numeric results of energy efficiency and energy demands of the dwellings, tables with information of all of them were prepared describing the envelope (walls, roofs and floors, glazing and shading devices), ventilation systems, heating and cooling equipment, solar collectors and hot water systems, respectively in Madalena, Table 1, and in Azenha de Cima, Table 2.

Table 1. Description of the housing envelope and equipment—Madalena.

\begin{tabular}{|c|c|c|}
\hline Envelope/Equipment & Description & $\begin{array}{l}\text { Thermal } \\
\text { transmittance/efficiency }\end{array}$ \\
\hline Façades & $\begin{array}{l}\text { Double pane wall, cored brick with } 11 \mathrm{~cm} \text { and hollow brick with } 15 \mathrm{~cm} \text {, with } \\
5 \mathrm{~cm} \text { of PUR }\end{array}$ & $0.43 \mathrm{~W} / \mathrm{m}^{2} \cdot{ }^{\circ} \mathrm{C}$ \\
\hline Inner walls* & $\begin{array}{l}\text { Double pane wall, solid brick with } 11 \mathrm{~cm} \text { and hollow brick with } 11 \mathrm{~cm} \text { with } 4 \\
\mathrm{~cm} \text { of Mineral Wool }\end{array}$ & $0.58 \mathrm{~W} / \mathrm{m}^{2} \cdot{ }^{\circ} \mathrm{C}$ \\
\hline Thermal bridges & $\begin{array}{l}\text { Double pane wall, cored brick with } 11 \mathrm{~cm} \text { and concrete with } 20 \mathrm{~cm} \text {, with } 5 \\
\mathrm{~cm} \text { of PUR }\end{array}$ & $0.84 \mathrm{~W} / \mathrm{m}^{2} \cdot{ }^{\circ} \mathrm{C}$ \\
\hline Exterior pavement & $\begin{array}{l}\text { Pre-stressed concrete "T" beams with lightweight expanded clay aggregate } \\
\text { (LECA) } 24 \mathrm{~cm} \text { thick, } 10 \mathrm{~cm} \text { light-weight EPS and concrete layer, } 1 \mathrm{~cm} \text { of } \\
\text { polyethylene foam, } 4 \mathrm{~cm} \text { regularization layer, } 4 \mathrm{~cm} \text { XPS }\end{array}$ & $0.79 \mathrm{~W} / \mathrm{m}^{2} \cdot{ }^{\circ} \mathrm{C}$ \\
\hline Interior pavement** & $\begin{array}{l}\text { Pre-stressed concrete "T" beams with lightweight expanded clay aggregate } \\
\text { (LECA) } 24 \mathrm{~cm} \text { thick, } 4 \mathrm{~cm} \text { light-weight EPS and concrete layer, } 1 \mathrm{~cm} \text { of } \\
\text { polyethylene foam, } 4 \mathrm{~cm} \text { regularization layer }\end{array}$ & $0.60 \mathrm{~W} / \mathrm{m}^{2} \cdot{ }^{\circ} \mathrm{C}$ \\
\hline Horizontal roof & $\begin{array}{l}\text { Pre-stressed concrete "T" beams with lightweight expanded clay aggregate } \\
\text { (LECA) } 25 \mathrm{~cm} \text { thick, } 10 \mathrm{~cm} \text { light-weight EPS and concrete layer, } 6 \mathrm{~cm} \text { XPS, } \\
4 \mathrm{~cm} \text { regularization layer, flexible PVC sheet membrane }\end{array}$ & $0.40 \mathrm{~W} / \mathrm{m}^{2} \cdot{ }^{\circ} \mathrm{C}$ \\
\hline Glazing & $\begin{array}{l}\text { Glazed anodized aluminum frames without thermal break, double-glazed } \\
6+10+4 \text {, with white-colored PVC outdoor blinds }\end{array}$ & $3.00 \mathrm{~W} / \mathrm{m}^{2} \cdot{ }^{\circ} \mathrm{C}$ \\
\hline Ventilation & $\begin{array}{l}\text { Mechanical ventilation that consists of common extractors installed on the } \\
\text { roof, with constant flow }\end{array}$ & Airflow of $100 \mathrm{~m}^{3} / \mathrm{h}$ \\
\hline Space heating & Manual or portable electric heaters & Efficiency $=1$ \\
\hline $\begin{array}{l}\text { Domestic Hot Water } \\
(\mathrm{DHW}) \text { preparation } \\
\text { system }\end{array}$ & $\begin{array}{l}\text { Collective set of solar collectors }{ }^{1} \mathrm{CPC} \text { AoSol (aperture area }=1,98 \mathrm{~m}^{2} \text {, } \\
\text { efficiency } \eta_{0}=0,726, \mathrm{a}_{1}=3,7 \mathrm{~W} / \mathrm{m}^{2} \cdot \mathrm{K}, \mathrm{a}_{2}=0,014 \mathrm{~W} / \mathrm{m}^{2} \cdot \mathrm{K}^{2} \text { ), facing South, } \\
\text { inclination of } 45^{\circ} \text { and indoor storage tank with collective support of DHW } \\
\text { preparation system that consists of Vulcan heater Sensor WT } 11 \mathrm{AM} 111 \\
\text { sealed, with an efficiency of } 0.87\end{array}$ & $\begin{array}{l}\text { Solar energy of } 2,086.00 \\
(\mathrm{~T} 3) \text { and } 1,565.00(\mathrm{~T} 2) \\
\text { kWh per year. }\end{array}$ \\
\hline
\end{tabular}

\footnotetext{
* Inner wall means wall separating heated spaces from non-heated spaces; ** Interior pavement means pavement
} separating heated spaces from non-heated spaces; UR - polyurethane rigid foam; XPS — expanded extruded polystyrene; EPS — expanded molded polystyrene; PVC — polyvinyl chloride; ${ }^{1}$ Solar collectors used in the Madalena building are in accordance with standard norms EN 12975 and also follow specific Keymark rules for solar thermal products. Solar collectors were chosen according to quality criteria concerning tubes and headers in the collector, materials of the absorber plate and insulation of sides and back of the solar collector [16]. 
Table 2. Description of the housing envelope and equipment-Azenha de Cima.

\begin{tabular}{|c|c|c|}
\hline Envelope/Equipment & Description & $\begin{array}{l}\text { Thermal } \\
\text { transmittance/efficiency }\end{array}$ \\
\hline Façades 1 & $\begin{array}{l}\text { Double pane wall, brick with } 11 \mathrm{~cm} \text { and hollow brick with } 11 \mathrm{~cm} \text {, no } \\
\text { insulation }\end{array}$ & $1.11 \mathrm{~W} / \mathrm{m}^{2} \cdot{ }^{\circ} \mathrm{C}$ \\
\hline Façades 2 & $\begin{array}{l}\text { Double pane wall, concrete wall with } 15 \mathrm{~cm}, 4 \mathrm{~cm} \text { air gap and hollow } \\
\text { brick with } 11 \mathrm{~cm} \text {, no insulation }\end{array}$ & $1.47 \mathrm{~W} / \mathrm{m}^{2} \cdot{ }^{\circ} \mathrm{C}$ \\
\hline Inner walls 1 & $15 \mathrm{~cm}$ hollow brick (in contact with the lift box) & $1.47 \mathrm{~W} / \mathrm{m}^{2} \cdot{ }^{\circ} \mathrm{C}$ \\
\hline Inner walls 2 & $\begin{array}{l}\text { Double pane wall, concrete wall with } 15 \mathrm{~cm}, 4 \mathrm{~cm} \text { air gap, and hollow } \\
\text { brick with } 11 \mathrm{~cm} \text {, no insulation (in contact with staircase and lift box) }\end{array}$ & $1.28 \mathrm{~W} / \mathrm{m}^{2} \cdot{ }^{\circ} \mathrm{C}$ \\
\hline Thermal bridges & $\begin{array}{l}\text { Double pane wall, brick with } 11 \mathrm{~cm} \text { and } 20 \mathrm{~cm} \text { thick concrete structure, } \\
\text { no insulation }\end{array}$ & $2.09 \mathrm{~W} / \mathrm{m}^{2} \cdot{ }^{\circ} \mathrm{C}$ \\
\hline Exterior pavement & $\begin{array}{l}\text { Pre-stressed concrete "T" beams, } 25 \mathrm{~cm} \text { hollow brick pots, } 5 \mathrm{~cm} \\
\text { regularization layer, } 4 \mathrm{~mm} \text { thick cork coating on the floor }\end{array}$ & $1.00 \mathrm{~W} / \mathrm{m}^{2} \cdot{ }^{\circ} \mathrm{C}$ \\
\hline Interior pavement & $\begin{array}{l}\text { Pre-stressed concrete " } \mathrm{T} \text { " beams, } 25 \mathrm{~cm} \text { hollow brick pots, } 5 \mathrm{~cm} \\
\text { regularization layer, } 4 \mathrm{~mm} \text { thick cork coating on the floor }\end{array}$ & $0.88 \mathrm{~W} / \mathrm{m}^{2} \cdot{ }^{\circ} \mathrm{C}$ \\
\hline Horizontal roof & $\begin{array}{l}\text { Pre-stressed concrete "T" beams, } 25 \mathrm{~cm} \text { hollow brick pots, lightweight } \\
\text { expanded clay aggregate (LECA) } 6 \mathrm{~cm} \text { thick, no insulation, } 4 \mathrm{~cm} \\
\text { regularization layer, fiber cement slabs resting on small brick walls } \\
\text { forming strongly ventilated attic. }\end{array}$ & $1.80 \mathrm{~W} / \mathrm{m}^{2} \cdot{ }^{\circ} \mathrm{C}$ \\
\hline Glazing 1 & $\begin{array}{l}\text { Simple sliding aluminum frames, with single } 4 \mathrm{~mm} \text { glazing with white- } \\
\text { colored PVC outdoor blinds }\end{array}$ & $3.9 \mathrm{~W} / \mathrm{m}^{2} \cdot{ }^{\circ} \mathrm{C}$ \\
\hline Glazing 2 & $\begin{array}{l}\text { Anodized aluminum frames with simple glass of } 4 \mathrm{~mm} \text {, without } \\
\text { sunscreen (in the laundry) }\end{array}$ & $6.2 \mathrm{~W} / \mathrm{m}^{2} \cdot{ }^{\circ} \mathrm{C}$ \\
\hline Ventilation & $\begin{array}{l}\text { Natural ventilation (blind boxes, no grids on the facades, no special } \\
\text { sealing devices) }\end{array}$ & Airflow of $60 \mathrm{~m}^{3} / \mathrm{h}$ \\
\hline Space heating & Manual or portable electric heaters & Efficiency $=1$ \\
\hline DHW preparation system & $\begin{array}{l}\text { DHW preparation system consists of Vulcan natural gas water heater } \\
\text { with an efficiency of } 0.39\end{array}$ & Efficiency $=0.39$ \\
\hline
\end{tabular}

* Inner wall means wall separating heated spaces from non-heated spaces; ** Interior pavement means pavement separating heated spaces from non-heated spaces.

Tables 1 and 2 show, for each envelope described, its thermal transmittance $\left(\mathrm{W} / \mathrm{m}^{2} \cdot{ }^{\circ} \mathrm{C}\right)$. It is also shown the annual solar energy produced by solar collectors $(\mathrm{kWh})$, efficiency of gas heaters and airflow of mechanical ventilators $\left(\mathrm{m}^{3} / \mathrm{h}\right)$. Thermal transmittance calculations shown in Tables 1 and 2 were based on thermal conductance and thermal resistance of the aforementioned materials [17-19]. It is possible to compare, for each type of envelope and equipment, the above mentioned values and conclude that Madalena values are significantly lower in what concerns thermal transmittance and higher concerning efficiency.

\subsubsection{Description of the Energy Performance of Dwellings}

To describe the energy performance of dwellings, an energy audit was made for each one, in order to determine its heating and cooling needs, as well as its needs of energy for DHW. The type of dwelling according to the number of rooms (T2 means two bedrooms) and the acclimatized floor area of the dwellings $(A u)$, shown in Table 3, were used for calculations, as well as the area of surrounding 
walls, pavements, roofs and glazing, along with their thermic transmittance or efficiency shown in Tables 1 and 2. These items are used to calculate the average annual needs for heating, cooling and DHW, per square meter of acclimatized area, shown in Figure 1, for the average dwelling.

Table 3. Description of type of dwelling and acclimatized area-Madalena vs. Azenha de Cima.

\begin{tabular}{ccccc}
\hline Building & Au-acclimatized floor area & T2 (Units) & T3 (Units) & T4 (Units) \\
\hline Madalena (sustainable) & 3222 & 17 & 22 & 0 \\
Azenha de Cima (traditional) & 2583 & 20 & 12 & 4 \\
\hline
\end{tabular}

Figure 1. Average annual needs for heating (Nic), cooling (Nvc) and DHW (Nac)—Madalena vs. Azenha de Cima.

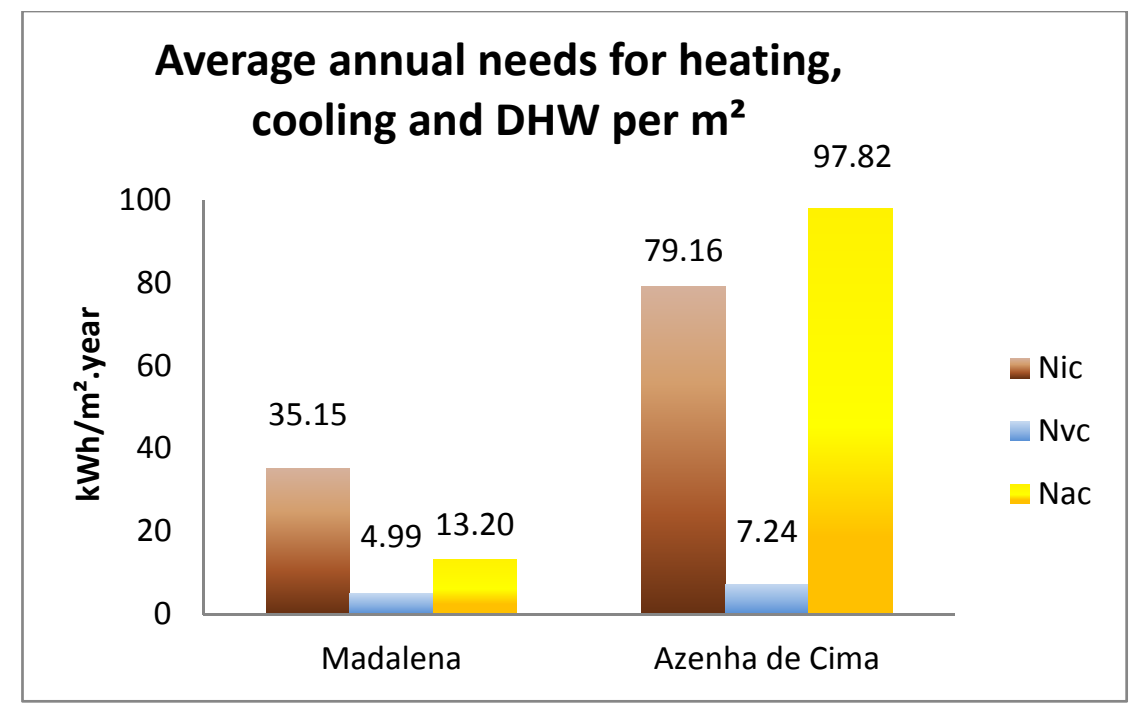

The items presented in Figure 1, have the following meaning [6-8]:

Nic: Average annual heating needs of electricity to keep the house at $20^{\circ} \mathrm{C}$ during the winter season $\left(\mathrm{kWh} / \mathrm{m}^{2} \cdot\right.$ year), per dwelling, for the total dwellings of the building;

$N v c$ : Average annual cooling needs of electricity to keep the house at $25{ }^{\circ} \mathrm{C}$ during the summer $\left(\mathrm{kWh} / \mathrm{m}^{2} \cdot\right.$ year), per dwelling, for the total dwellings of the building;

Nac: Average annual DHW energy needs to ensure a daily consumption of 40 liters of hot water per inhabitant in the dwelling, in $\mathrm{kWh} / \mathrm{m}^{2}$.year $(\mathrm{T} 1=2$ inhabitants, $\mathrm{T} 2=3$ inhabitants, $\mathrm{T} 3=4$ inhabitants, $\mathrm{T} 4=5$ inhabitants), per dwelling, for the total dwellings of the building.

From Figure 1 it is possible to conclude that a sustainable construction is prepared to spend $56 \%$ less electricity in space heating and $86 \%$ less natural gas in DHW, per square meter. Considering that the average of a dwelling in Madalena is $82.6 \mathrm{~m}^{2}$ and the average areas of a dwelling in Azenha de Cima is $71.8 \mathrm{~m}^{2}$, the annual heating needs and DHW needs for the average dwelling of each building are presented in Table 4. 
Table 4. Annual energy needs for the average dwelling-Madalena vs. Azenha de Cima.

\begin{tabular}{ccccc}
\hline Building & $\begin{array}{c}\text { Average floor } \\
\text { area }\left(\mathbf{m}^{\mathbf{2}}\right)\end{array}$ & $\begin{array}{c}\text { Annual heating } \\
\text { needs (kWh/year) }\end{array}$ & $\begin{array}{c}\text { Annual cooling } \\
\text { needs (kWh/year) }\end{array}$ & $\begin{array}{c}\text { Annual DHW } \\
\text { needs (kWh/year) }\end{array}$ \\
\hline Madalena (sustainable) & 82.6 & 2,903 & 412 & 1,090 \\
Azenha de Cima (traditional) & 71.8 & 5,684 & 520 & 7,023 \\
\hline
\end{tabular}

These results show that a non-sustainable dwelling can spend, for heating, twice as much energy as a sustainable one, and is very probable to spend, for the standard comfort, almost seven times more energy in DWH.

The values of Nic, Nvc and Nac mentioned in Figure 1 are quantified using calculation methods included in the Portuguese thermal regulations [7]. The following tables also show for each dwelling the values of annual energy needs as well as their maximum allowable values. Relation between Ntc and $\mathrm{Nt}$ is used to determine $\mathrm{CO}_{2}$ emissions and the Efficiency Energy Rating (EER) Label [6].

Energy rating, as normalized by Portuguese Law [6-8], relates the value of annual primary energy consumption with the maximum allowable annual primary energy consumption, as follows:

$0.00<\mathrm{Ntc} / \mathrm{Nt} \leq 0.25$ : "A +" Class; $0.25<\mathrm{Ntc} / \mathrm{Nt} \leq 0.50$ : "A" Class; $0.50<\mathrm{Ntc} / \mathrm{Nt} \leq 0.75$ : "B" Class;

$0.75<\mathrm{Ntc} / \mathrm{Nt} \leq 1.00$ : "B-" Class; $1.00<\mathrm{Ntc} / \mathrm{Nt} \leq 1.50$ : "C" Class; $1.50<\mathrm{Ntc} / \mathrm{Nt} \leq 2.00$ : "D" Class;

$2.00<\mathrm{Ntc} / \mathrm{Nt} \leq 2.50$ :"E" Class; $2.50<\mathrm{Ntc} / \mathrm{Nt} \leq 3.00$ : "F" Class; $\mathrm{Ntc} / \mathrm{Nt}>3,00$ : "G" Class;

In which:

Ntc: Annual primary energy consumption, in kilogram(s) of oil equivalent (kgoe);

$\mathrm{Nt}$ : Maximum allowable values of annual primary energy consumption (kgoe).

Considering the same regulations, the EER of the 39 dwellings of Madalena is " $A$ " and the EER of the all 36 dwellings of Azenha de Cima is " $C$ ". The " $A$ " label of Madalena means that the needs of primary energy for this building are less than $50 \%$ than the maximum needs of primary energy allowed. On the other hand, the "C" class in Azenha de Cima means that the needs of primary energy for this traditional building are higher up to $50 \%$ more than the maximum needs of primary energy allowed by new regulations.

In order to compare the annual emissions of $\mathrm{CO}_{2}$ of the average dwelling of each building, it is presented its value in Figure 2. It is possible to see that the estimated emissions for the building efficiency are almost three times higher in Azenha de Cima than in Madalena. 
Figure 2. Average $\mathrm{CO}_{2}$ annual emissions-Madalena vs. Azenha de Cima.

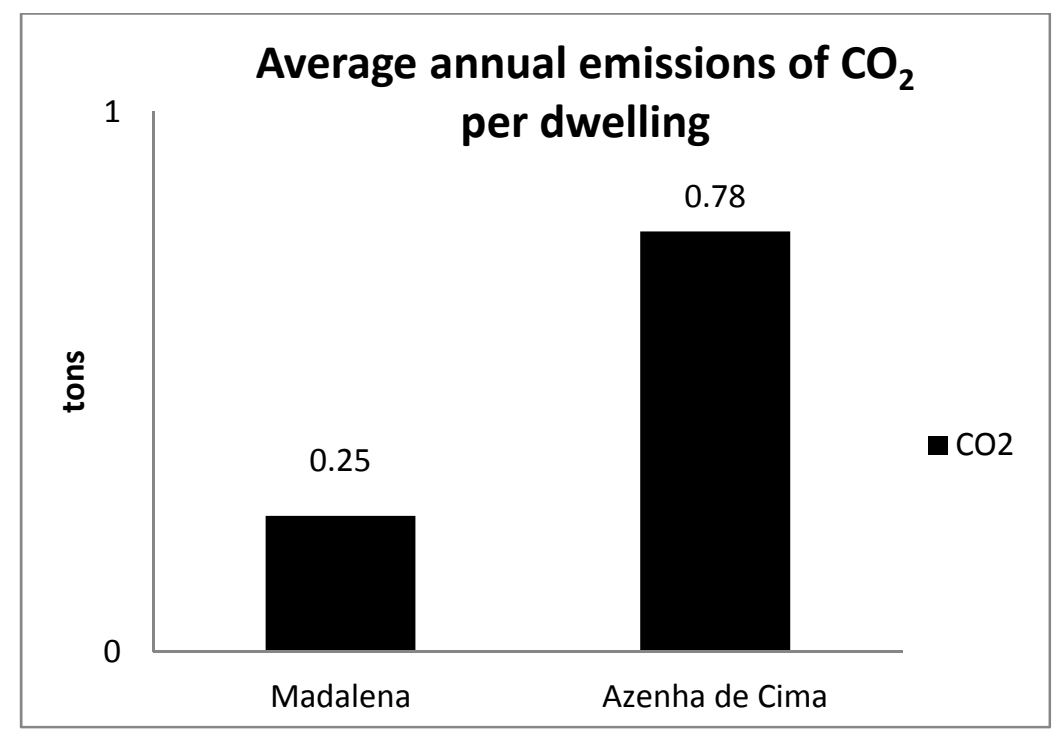

According to calculations of global heating, cooling and DHW needs for each building, it is possible to present their values for each building.

These results, calculated for Madalena building (sustainable), with 39 dwellings, and for Azenha de Cima building (traditional), with 36 dwellings, are very clear about the importance of thermal insulation, efficient heaters and of use of solar collectors, as shown in Table 5.

Table 5. Global annual energy needs-Madalena vs. Azenha de Cima.

\begin{tabular}{cccc}
\hline Building & $\begin{array}{c}\text { Heating needs in } \\
\text { winter kWh/year }\end{array}$ & $\begin{array}{c}\text { Cooling needs in } \\
\text { summer kWh/year }\end{array}$ & $\begin{array}{c}\text { DHW needs } \\
\text { kWh/year }\end{array}$ \\
\hline Madalena (sustainable) & 113,253 & 16,078 & 42,530 \\
Azenha de Cima (traditional) & 202,139 & 18,548 & 250,790 \\
\hline
\end{tabular}

According to Table 5, efficient thermal insulation is responsible for $46 \%$ less energy in heating during winter season; efficient gas heaters and solar collectors are the cause of Madalena building spending $83 \%$ less energy in DHW.

\subsubsection{Energy Costs for Heating, Cooling and DHW}

Based on numerical data from Figure 1, the annual costs (in euro) for the demands of each type of energy were calculated for the Madalena average dwelling and for the Azenha de Cima average dwelling, as shown in Table 6. These costs were obtained taking into consideration the annual heating, cooling and DHW needs and the cost of domestic gas and electricity at the time of the case study-September 2011 ( $€ 0.12 / \mathrm{kWh}$ of electricity and $€ 0.06 / \mathrm{kWh}$ of natural gas). 
Table 6. Average expectable energy costs per dwelling-Madalena vs. Azenha de Cima.

\begin{tabular}{ccccc}
\hline Building & $\begin{array}{c}\text { Average floor } \\
\left.\text { area ( } \mathbf{( m}^{\mathbf{2}}\right)\end{array}$ & $\begin{array}{c}\text { Annual cost for } \\
\text { heating (euro) }\end{array}$ & $\begin{array}{c}\text { Annual cost for } \\
\text { cooling (euro) }\end{array}$ & $\begin{array}{c}\text { Annual cost for } \\
\text { DWH (euro) }\end{array}$ \\
\hline Madalena (sustainable) & 82.6 & 348.36 & 49.44 & 65.40 \\
Azenha de Cima (traditional) & 71.8 & 682.08 & 62.40 & 421.38 \\
\hline
\end{tabular}

The estimated annual costs for heating, cooling and water heating obtained for the average dwelling allow, by summing them, to determine its total expense on energy. Therefore, it follows that the expected average annual expenditure on energy for heating, cooling and heating domestic hot water, is, per dwelling, of $€ 463.20$ for the building of Madalena and $€ 1,165.86$ for Azenha de Cima.

These costs were calculated for the purpose of maintaining a level of comfort for the residents, with their house heated permanently at $20{ }^{\circ} \mathrm{C}$ during winter season, cooled permanently at $25{ }^{\circ} \mathrm{C}$ during summer and to ensure a daily consumption of 40 liters of hot water per inhabitant in the dwelling.

But, in opposition to the optimum levels of indoor comfort, involving the costs above mentioned, it is possible to determine the cost actually spent in energy for heating and for DHW, determined by a monitoring procedure, as shown in Section 2.4.

\subsection{Analysis of the Results of Efficiency Studies}

To analyze the differences in energy demands between a building with sustainable construction characteristics (Madalena) and a building with traditional construction features (Azenha de Cima), it is important to examine the main data of these buildings and to decide to what extent the data is important to the comparative analysis. According to Table 7, Madalena building has only three dwellings more than Azenha de Cima, which makes the two buildings comparable as concerns size. When comparing floor areas, Madalena building possesses 24.7\% more area than Azenha de Cima $\left(3,222.00 \mathrm{~m}^{2}\right.$ against 2,583.00 $\mathrm{m}^{2}$ ). This means that Madalena building has, in relation to Azenha de Cima building, more average floor area per dwelling $\left(82.6 \mathrm{~m}^{2}\right.$ against $\left.71.8 \mathrm{~m}^{2}\right)$, which makes housing more comfortable but at the same time, leads to an increase in its envelope area, with a consequent increase in the heat losses and energy needs.

Table 7. Description of areas, dwellings and inhabitants-Madalena vs. Azenha de Cima.

\begin{tabular}{cccc}
\hline Building & Un & Madalena & Azenha de Cima \\
\hline Number of dwellings & Un & 39 & 36 \\
Floor area of all dwellings & $\mathrm{m}^{2}$ & $3,222.00$ & $2,583.00$ \\
Average area of dwellings & $\mathrm{m}^{2} / \mathrm{dwelling}$ & 82.6 & 71.8 \\
Number of inhabitants in buildings & Un & 139 & 128 \\
Average population by dwelling & Un/dwelling & 3.56 & 3.56 \\
\hline
\end{tabular}

For the analysis, as shown in Table 7, for each building, and taking into account that a T2 dwelling has, on average, three persons, a T3 has four residents and a T4 has five persons, Madalena building contains 139 inhabitants and Azenha de Cima building houses 128 inhabitants. Given that the average number of inhabitants per dwelling in cooperative housing developments is 3.5, corresponding to an average distribution of types of $10 \%$ for $\mathrm{T} 1,40 \%$ for type $\mathrm{T} 2,40 \%$ for $\mathrm{T} 3$ and $10 \%$ for T4, it appears 
that the average number of residents of Madalena building is 3.56 inhabitants per dwelling and the average number of people in the building in Azenha de Cima is 3.56 people per dwelling, so they are equivalent in the average number of people per dwelling. These values are slightly higher than the average population density of cooperative housing developments [11,13,20] and configure a cooperative housing density that has an impact on energy consumption in housing, particularly in energy consumption for water heating.

Based on the calculations of energy requirements for winter and summer comfort, as well as for producing hot water, as far as areas, dwellings and inhabitants are concerned, it is possible to draw two main conclusions about the performance and energy efficiency of the dwellings described in Table 8:

- Madalena presents a cost of annual energy demand per $\mathrm{m}^{2}$ of floor area $63.8 \%$ lower than the Azenha de Cima building ( $€ 5.61 / \mathrm{m}^{2}$ against $€ 16.25 / \mathrm{m}^{2}$ ). This difference shows that the choice of households to purchase cooperative housing with sustainable building features, allows monthly savings, for a dwelling with $75.00 \mathrm{~m}^{2}$, of $€ 798.00$ per year, equivalent to a monthly average saving of $€ 66.50$.

- The estimated annual energy demand for water heating, per capita, in the Madalena building is 85.6\% lower than the estimated annual demand in the Azenha de Cima building ( $€ 18.35$ against $€ 118.51)$. This difference shows that the option for providing energy-efficient equipment, such as solar collectors and high-efficient water heaters, translates into high savings in energy over the lifetime of the building.

Table 8. Description of energy demands costs—Madalena vs. Azenha de Cima.

\begin{tabular}{cccc}
\hline Energy needs and costs & Un & Madalena & Azenha de Cima \\
\hline Global energy needs & $\mathrm{kWh} / \mathrm{year}$ & $171,861.00$ & $471,477.00$ \\
Energy needs per $\mathrm{m}^{2}$ of floor area & $\mathrm{kWh} / \mathrm{m}^{2} \cdot$ year & 53.34 & 182.53 \\
Annual energy costs per building & $€$ & $18,065.00$ & $41,970.00$ \\
Annual energy costs per $\mathrm{m}^{2}$ of floor area & $€ / \mathrm{m}^{2}$ & 5.61 & 16.25 \\
Annual energy cost for water heating per capita & $€ /$ person & 18.35 & 118.51 \\
\hline
\end{tabular}

According to calculations of global heating, cooling and DHW needs for each building, it is possible to present their values for each building.

These results, calculated for Madalena building (sustainable), with 39 dwellings, and for Azenha de Cima building (traditional), with 36 dwellings, are very clear about the importance of thermal insulation, efficient heaters and of use of solar collectors, as shown in Table 9.

Table 9. Global annual energy needs and solar gains-Madalena vs. Azenha de Cima.

\begin{tabular}{ccccccc}
\hline Building & $\begin{array}{c}\text { Solar gains } \\
\text { in winter } \\
\mathbf{k W h} / \mathbf{y e a r}\end{array}$ & $\begin{array}{c}\text { Heating } \\
\text { needs } \\
\mathbf{k W h} / \mathbf{y e a r}\end{array}$ & $\begin{array}{c}\text { Solar gains } \\
\text { in summer } \\
\mathbf{k W h} / \mathbf{y e a r}\end{array}$ & $\begin{array}{c}\text { Cooling } \\
\text { needs } \\
\mathbf{k W h} / \mathbf{y e a r}\end{array}$ & $\begin{array}{c}\text { Solar gains } \\
\text { in collectors } \\
\mathbf{k W h} / \mathbf{y e a r}\end{array}$ & $\begin{array}{c}\text { DHW needs } \\
\mathbf{k W h} / \mathbf{y e a r}\end{array}$ \\
\hline $\begin{array}{c}\text { Madalena } \\
\text { (sustainable) }\end{array}$ & 62,088 & 113,253 & 18,913 & 16,078 & 72,497 & 42,530 \\
$\begin{array}{c}\text { Azenha de Cima } \\
\text { (traditional) }\end{array}$ & 42,490 & 202,139 & 40,062 & 18,548 & $\begin{array}{c}\text { Not } \\
\text { available }\end{array}$ & 250,790 \\
\hline
\end{tabular}


According to Table 9, a higher percentage of area of glazing in the façades (37.5\% against 24.8\%) provides Madalena building 46\% more solar gains in winter; efficient thermal insulation is responsible for $44 \%$ less energy in heating and cooling; efficient gas heaters and solar collectors are the cause of Madalena building spending 83\% less energy in DHW.

\subsection{Monitoring Procedure of Costs in Energy in Residential Housing Cooperative}

For one complete year, the same dwellings presented in Section 2.2 were monitored through monthly readings, in what concerns electricity and natural gas consumptions, and their consumptions were registered for further statistic treatment.

The purpose of monitoring was to obtain real average consumptions, per dwelling, for indoor heating and for DHW heating. The results of monitoring are shown in Table 10, in what concerns average consumption for heating, expressed in $\mathrm{kWh} / \mathrm{m}^{2}$ year. Therefore, it is possible to show, in the following section, the results of real consumptions of the residents in electricity for heating and natural gas for DHW. There are no results for cooling, because none of the dwelling possesses cooling devices.

\subsubsection{Real Heating and DWH Energy Consumptions in Dwellings}

As shown in Table 10, real consumptions per square meter of electricity for indoor heating are lower in Madalena than in Azenha de Cima dwellings like it was observed for the estimated values. The reason is that Madalena possesses important differences in what concerns thermal insulation, so that residents spend a very limited amount of energy, opposed to the traditional building, which spend more to obtain similar, but minimum, level of comfort.

On the other hand, as the inhabitants of Azenha de Cima don't possess solar collectors or efficient heaters for DHW, they spend almost three times more energy to heat water, per square meter than the Madalena inhabitants.

Table 10. Average annual consumptions for heating and DHW per $\mathrm{m}^{2}$-Madalena $v s$. Azenha de Cima.

\begin{tabular}{|c|c|c|c|}
\hline Building & $\begin{array}{c}\text { Annual consumption } \\
\text { for heating } \\
\left(\mathbf{k W h} / \mathbf{m}^{2} \cdot \text { year }\right) \\
\end{array}$ & $\begin{array}{c}\text { Annual consumption } \\
\text { for } \mathrm{DHW} \\
\left(\mathrm{kWh} / \mathrm{m}^{2} \cdot \text { year }\right) \\
\end{array}$ & $\begin{array}{c}\text { Total annual } \\
\text { consumption for heating } \\
\text { and DHW }\left(\mathrm{kWh} / \mathrm{m}^{2} \cdot \text { year }\right)\end{array}$ \\
\hline Madalena (sustainable) & 4.80 & 8.03 & 12.83 \\
\hline Azenha de Cima (traditional) & 7.80 & 21.90 & 29.70 \\
\hline
\end{tabular}

\subsubsection{Heating and DHW Consumption Costs}

Based on numerical data from Table 10, the annual costs (in euro) per $\mathrm{m}^{2}$ for the demands of each type of energy were calculated for the Madalena building and for the Azenha de Cima building, as shown in Table 11. These costs were obtained taking into consideration the same cost of energy considered in Section 2.2.4. So, average real energy costs per dwelling shown in Table 11 are obtained considering the cost of energy (€0.12 per kWh of electricity and $€ 0.06$ per kWh of natural gas) applied to consumptions shown in Table 10. 
Table 11. Average real energy costs per dwelling_-Madalena vs. Azenha de Cima.

\begin{tabular}{|c|c|c|c|}
\hline Building & $\begin{array}{c}\text { Annual cost for } \\
\text { heating }\left(\mathrm{euro} / \mathrm{m}^{2} \cdot \text { year }\right)\end{array}$ & $\begin{array}{c}\text { Annual cost for } \\
\text { DHW (euro } / \mathbf{m}^{2} \cdot \text { year) }\end{array}$ & $\begin{array}{c}\text { Total annual cost for } \\
\text { heating and DHW } \\
\left(\text { euro } / \mathbf{m}^{2} \cdot \text { year }\right)\end{array}$ \\
\hline Madalena (sustainable) & 0.58 & 0.48 & 1.06 \\
\hline Azenha de Cima (traditional) & 0.94 & 1.31 & 2.25 \\
\hline
\end{tabular}

It is possible to observe that the energy consumptions registered by monitoring are much lower than the calculated energy needs previously showed. This is a common situation in Portugal although not so expressive. Traditionally and for cultural reasons, residences do not comply with the legal comfort levels and it is usual to have indoor temperatures much lower than the standard $20{ }^{\circ} \mathrm{C}$ in winter and higher than the standard $25^{\circ} \mathrm{C}$ in summer (temperature values used for the energy needs estimation). In this particularly case, this situation is aggravated by the low income typical of cooperative residents that are not able to spend a higher amount in heating or DHW and so they limit the use of energy to the minimum. Other reason is related to the fact that these dwellings were not provided with efficient heating systems in order not to exceed the maximum allowed construction cost and by that beneficiate of the tax reductions allowed by Portuguese Law. The use of efficient systems would provide an important decrease of energy in space heating when compared to portable electric heaters, which are the only devices used by inhabitants for indoor heating.

Cooperative housing has been considered, for several years, as low quality housing. However, during the last years, an effort has been made to build with higher quality standards and applying energy efficiency measures without increasing the costs of construction.

The result has been a significant increase of indoor comfort while maintaining purchase costs and strongly reducing running costs, as shown in the above figures and tables.

\section{Payback Period of Sustainable Construction}

This study shows that it is possible to measure cost benefits in sustainable cooperative construction. It is expected that a medium-sized sustainable cooperative dwelling of $750 \mathrm{~m}^{2}$ spends on electricity and natural gas, per year, less $€ 798,00[(16.25-5.61) \times 750]$ than a similar sized dwelling of traditional cooperative construction. This difference is due mainly to a highly-efficient envelope and also to the use of efficient solar collectors and gas heaters.

Consulting the technical and financial data of Madalena project, it is possible to present a list of highly-efficient materials and equipment, as well as their costs, which are described in Table 12. As none of these materials and equipment were used in the Azenha de Cima project, it is possible to assume that the values shown in Table 12 represent the increase of costs associated with the implementation of sustainable construction features.

The costs of these materials and equipment, for the 39 dwellings, were calculated at $€ 165,463.00$. This means that the cost of sustainable construction in Madalena building, per dwelling, is $€ 51.35$ per square meter, so the increase of cost in a $750 \mathrm{~m}^{2}$ dwelling is $€ 51.35 \times 750 \mathrm{~m}^{2}=€ 3,851.25$. Assuming that the sustainable building of Madalena spends $€ 1,165.86-€ 463.20=€ 702.66$ less per dwelling and per year than the traditional building of Azenha de Cima, the payback period is of $€ 3,851.25 / € 702.66=5.5$ years. 
Table 12. Cost of efficient materials and equipment of Madalena project and payback period for sustainable construction with standard comfort energy consumptions ( 39 dwellings).

\begin{tabular}{cc}
\hline Efficient materials and equipment & Cost (€) \\
Thermal insulation in façades & $33,203.00$ \\
Thermal insulation in interior walls & $2,470.00$ \\
Thermal insulation in interior floors & $6,265.00$ \\
Thermal insulation in roofs & $7,229.00$ \\
Windows of low permeability to the wind & $8,666.00$ \\
Double glazing with 12 mm air gap & $13,865.00$ \\
Permanent mechanical ventilation and air inlet grids & $22,210.00$ \\
High-efficient gas heater & $7,800.00$ \\
Complete system of solar collectors & $63,755.00$ \\
Total costs of efficient materials and equipment for 39 dwellings & $165,463.00$ \\
Increase of cost per square meter due to efficient construction & 51.35 \\
Increase of cost in a 75,0 m² dwelling due to efficient construction & $3,851.25$ \\
Cost of construction of a 75,0 m $^{2}$ dwelling & $68,770.00$ \\
Percentage of sustainable construction on global cost $(\%)$ & 5.60 \\
Payback period for efficient construction & 5.5 years \\
\hline
\end{tabular}

* Solar collectors and ventilation maintenance cost are included in general maintenance of the building, not brought to this study and represent less than $5 \%$ of running costs, therefore excluded from calculations.

The efficient solution for DHW needs, in itself, has an even shorter payback period. According to results as shown in Table 12, the cost for a complete system of solar collectors for the 39 dwellings is $€ 63,755.00$, or $€ 1,634.74$ per dwelling. It is possible to calculate the medium cost, per dwelling and per year, of the annual DHW energy needs expected to both buildings, which is of $€ 65.40$ for the Madalena building and of $€ 421.38$ for the Azenha de Cima building. The savings on $€ 421.38-€ 65.40=€ 355.98$ by using solar collectors and efficient gas-heaters is payable in $€ 1,634.74 / € 355.98=4.6$ years. The building systems and efficient equipment included in this list led to the " $\mathrm{A}$ " class of efficiency of the dwellings in Madalena building.

In what concerns monitored consumptions, knowing that the use of sustainable construction has lower running costs in energy, when compared with traditional construction, it is also possible to calculate its payback period for an acceptable comfort level for cooperative residents, using the difference between total annual real costs for heating and DHW between Madalena and Azenha de Cima, as shown in Table 11. This payback period is naturally higher than the one calculated for standard comfort levels but is, nevertheless, smaller than the life cycle of the building, as shown in Table 13. No extra or rental costs were considered in this study mainly because this was not the purpose of the paper and the dwellings are not rented. All the dwellings are owned by their inhabitants.

Table 13. Payback period for sustainable construction with low but acceptable energy consumptions.

\begin{tabular}{cc}
\hline Increase of cost and annual savings & Cost (€) \\
\hline Increase of cost per square meter due to efficient construction & 51.35 \\
Savings in energy consumption per $\mathrm{m}^{2} \cdot$ year due to efficient construction & 1.19 \\
Payback period for efficient construction for minimum but acceptable consumptions & 43 years \\
\hline
\end{tabular}


The above payback periods are considered to be the lower and the higher limits of an interval where the payback period should fit, according to the level of comfort chosen by the residents. In other words, the higher level of comfort in heating, cooling and using DHW, in their dwellings, the lower would be the payback period, and vice-versa.

\section{Conclusions and Recommendations}

The presented results, making up part of a broader research project, point to a positive impact on cooperative housing under controlled costs, when using sustainable construction. This positive impact is achieved due to the following main factors:

- First, it is considered that general reduction of heat loss through construction elements, as is usually considered by designers, is not sufficient; it is recommended to optimize efficiency of the inner and outer envelope. According to the data shown in Tables 10-12, the increase of cost by using very efficient techniques of insulation of the envelope is $5.6 \%$ of the construction cost and the decrease of heat loss achieved varies from $52 \%$ (according to real consumptions) to $65 \%$ (according to estimated energy needs) when compared with traditional construction;

- In second place, solar collectors and water gas heaters of high efficiency are recommended in the design, since the increase of cost using these devices, when compared with standard ones, is small taking into account the decrease of energy use they provide. According to the data shown in Tables 5, 6 and 9, the increase of cost by using solar collectors and efficient gas heaters is $4.6 \%$ of the construction cost and the decrease of cost in using DHW achieved varies from 58\% (according to real consumptions) to $84 \%$ (according to estimated energy needs) when compared with traditional construction;

- In third place, it is possible to conclude that the inclusion in design of efficient techniques of insulation of the envelope, solar collectors and water gas heaters, has a payback period that varies between 5.5 to 43 years, according to the level of comfort adopted by residents in their dwellings.

However, the most positive impact of this study is to show that it is possible to build using sustainable construction principles at controlled costs, i.e., at low cost. In fact, it is a common thought that, to reach a high Energy Efficiency standard, houses and apartments must incorporate sophisticated, efficient but expensive solutions.

Cooperative housing is targeted at lower and mid-lower classes, who cannot afford buying expensive residences. In this study, made by using a sample of 75 low cost cooperative dwellings, it is possible to prove that sustainable construction can be equally efficient, with high energy efficiency labels but done at low cost. This type of construction provides an average increase of $€ 51.35$ per square meter over the cost of traditional construction, and also provides annual savings in indoor heating, indoor cooling and DHW between $€ 1.19$ and $€ 10.64$ per square meter.

However, despite these positive results, we must continue to broaden the studies concerning the quantification of maintenance and operating costs related to the techniques and systems used, including its social and economic impact on the savings of economic resources of the families living in cooperative ventures during the lifetime of the building. In future, it is interesting to continue to act [2] 
adequately promoting sustainable construction and renovation, in a comprehensive manner considering all aspects of sustainable construction.

\section{References}

1. Mourão, J.; Pedro, J.B. Sustainable housing: From consensual guidelines to broader challenges. In Portugal SB 07 Sustainable Construction, Materials and Practices; IOS Press: Amsterdam, The Netherlands, 2007.

2. Edwards, B. Guía Básica de la Sostenibilidad (in Spanish), 3rd ed.; Editorial Gustavo Gili: Barcelona, Spain, 2005.

3. Coelho, A. A promoção de habitação cooperativa com qualidade e custos controlados (in Portuguese). In Encontro Nacional sobre Qualidade e Inovação na Construção-QIC 2006; LNEC: Lisboa, Portugal, 2006; pp. 21-24.

4. Halliday, S.; Stevenson, F. Summary Report on Sustainable Construction and the Regulatory Framework; Gaia Research Edimburg: Edimburgh, UK, 2004.

5. Halliday, S. Sustainable Construction, 1st ed.; Elsevier: Oxford, UK, 2009.

6. Decree-Law Nr. 78/2006, Energy Certification and Indoor Air Quality in Buildings; Portuguese Legislation: Lisbon, Portugal, 2006.

7. Decree-Law Nr. 80/2006, Regulation of the Thermal Behaviour Characteristics in Buildings; Portuguese Legislation: Lisbon, Portugal, 2006.

8. Energy Performance of Buildings Directive (EPBD). Directive 2002/91/CE, Directive of the European Parliament and of the European Council, on the Energy Performance of Buildings; EPBD: Brussels, Belgium, 2002.

9. Pinheiro, M. Será que a sustentabilidade na construção é mais onerosa (in Portuguese)? In Actas do Congresso de Inovação na Construção Sustentável (CINCOS'08); Plataforma para a Construção Sustentável: Curia, Portugal, 2008,

10. Roaf, S.; Fuentes, M.; Thomas, S. Ecohouse, 3rd ed.; Elsevier Architectural Press: Oxford, UK, 2007.

11. Arnaldo, F.; Magano, O. Habitação Cooperativa em Portugal 1974-1991 (in Portuguese); Federação Nacional de Cooperativas de Habitação Económica (FENACHE): Porto, Portugal, 1992.

12. Santos, I.; Soares, L.; Teixeira, J. Guidelines for a good practices manual on sustainable construction. In SB07 Lisbon-Sustainable Construction, Materials and Practices: Challenge of the Industry for the New Millenium; IOS Press: Amsterdam, The Netherlands, 2007.

13. Norbiceta. The First Cooperative Development of Sustainable Housing in Portugal (in Portuguese); Germina: Lisbon, Portugal, 2007.

14. Law Nr. 85/98, Tax Cooperative Statute; Portuguese legislation: Lisbon, Portugal, 1998.

15. Outrequin, P. Report on Social and Economic Aspects and Monitoring; EU SHE (Sustainable Housing in Europe) Project; SHE Sustainable Housing in Europe: Rome, Italy, 2006.

16. Nicholls, R. The Green Building Bible: The Low Energy Design Technical Reference; 4th ed.; Green Building Press: Llandysul, UK, 2008; pp. 43-46.

17. Kibert, C. Sustainable Construction, Green Building Design and Delivery, 2nd ed.; John Wiley and Sons, Inc.: Hoboken, NJ, USA, 2008. 
18. Santos, C. Thermal Transmittance Values for Elements of Building Envelope, ITE50; LNEC: Lisbon, Portugal, 2007.

19. Strother, E.; Turner, W. Thermal Insulation Building Guide; Robert Krieger Publishing Company, Inc.: Malabar, FL, USA, 1990.

20. Lusardi, A. The Role the Co-Operative Housing Sector Can Play in Combating Climate Change; The EU SHE (Sustainable Housing in Europe) Project: Roman, Italy, 2007.

(C) 2013 by the authors; licensee MDPI, Basel, Switzerland. This article is an open access article distributed under the terms and conditions of the Creative Commons Attribution license (http://creativecommons.org/licenses/by/3.0/). 